\title{
Distribusi Bahan Organik pada Sedimen Permukaan Teluk Kelabat, Pulau Bangka
}

\author{
Mohammad Agung Nugraha* dan Mu'alimah Hudatwi
}

\author{
Program Studi llmu Kelautan, Fakultas Pertanian, Perikanan, dan Biologi, \\ Universitas Bangka Belitung \\ Kampus Terpadu UBB, Balunijuk, Kab.Bangka, Kepulauan Bangka Belitung 33172 Indonesia \\ Email: mohammad.agung.n2361@gmail.com
}

\section{Abstract \\ Distribution of Organic Matter in The Surface Sediments of Kelabat Bay, Bangka Island}

Transport of organic material in coastal areas plays an important role in the global biogeochemical cycle. The purpose of this study was to examine the distribution of organic material in sediments and to identify sources of organic material in the Kelabat Bay waters. TOC and TN sediments were analyzed by the Walkley Black and Kjeldahl method. The value of TOC, TN, and $\mathrm{C} / \mathrm{N}$ ratio obtained in the Kelabat Bay waters sediments ranged from 0.04-7.25\%, 0.04-0.14\%, and 0.67-65.91. The distribution of TOC, TN, and C/N ratio in Kelabat Bay sediments shows that the value in the inner Kelabat Bay is higher than the outside. The source of organic material input in the inner Kelabat Bay comes mainly from terrestrial, while the outer Kelabat Bay mainly comes from aquatic.

Keywords : C/N ratio, organic matter, sediment, Kelabat

\begin{abstract}
Abstrak
Transport bahan organik pada wilayah pesisir memainkan peran penting dalam siklus biogeokimia secara global. Tujuan penelitian ini untuk mengkaji distribusi bahan organik pada sedimen serta identifikasi sumber bahan organik perairan Teluk Kelabat. TOC dan TN sedimen dianalisis dengan metode Walkley Black dan Kjeldahl. Nilai TOC, TN, dan rasio C/N yang diperoleh pada sedimen perairan Teluk Kelabat berkisar antara 0,04-7,25\%, 0,04-0,14\%, dan 0,67-65,91. Distribusi TOC, TN, serta rasio C/N pada sedimen Teluk Kelabat memperlihatkan nilai pada Teluk Kelabat bagian dalam lebih tinggi dibandingkan bagian luar. Sumber masukan bahan organik pada Teluk Kelabat bagian dalam utamanya berasal dari terestrial, sedangkan Teluk Kelabat bagian luar utamanya berasal dari akuatik.
\end{abstract}

Kata kunci : rasio C/N, bahan organik, sedimen, Kelabat

\section{PENDAHULUAN}

Bahan organik pada sedimen perairan laut merupakan campuran senyawa organik kompleks yang sumbernya berasal dari laut dan terestrial (Gao et al., 2012). Transport bahan organik pada area pesisir memainkan peran penting dalam siklus biogeokimia secara global (Li et al., 2016). Karbon dan nitrogen merupakan dua komponen utama pada bahan organik. Kandungan bahan organik pada sedimen tergantung dari beberapa faktor, seperti karakteristik sedimen, laju degradasi oleh bakteri, produktivitas pada kolom air, dan masukan dari terestrial (Burone et al., 2003).

Rasio unsur karbon organik total (TOC) dan total nitrogen (TN), yang biasanya dinyatakan sebagai $\mathrm{C} / \mathrm{N}$ atau TOC/TN, telah banyak digunakan, untuk menjelaskan sumber dan nasib bahan organik di lingkungan perairan (Gao et al., 2012). Kontribusi relatif masukan bahan organik dari 
alotonus (terestrial) dan autotonus (akuatik)dinilai dengan menggunakan rasio $\mathrm{C} / \mathrm{N}$. Bahan organik dari tumbuhan tingkat tinggi memiliki kandungan nitrogen yang rendah dan memiliki nilai rasio $\mathrm{C} / \mathrm{N}$ yang lebih tinggi. Fitoplankton kaya akan senyawa nitrogen dan rendahnya nilai rasio $\mathrm{C} / \mathrm{N}$ pada sedimen merupakan indikasi dominannya bahan organik dari laut atau akuatik (Burone et al., 2003).

Teluk Kelabat terbagi atas dua bagian, yaitu bagian luar dan dalam. Teluk Kelabat (Pulau Bangka) terdapat di Provinsi Kepulauan Bangka Belitung. Aktivitas pada lahan atas dan sekitar teluk yaitu pemukiman/ domestik, perkebunan, pertanian, penambangan timah inkonvensional, wisata, dan penangkapan ikan. Adanya aktivitas antropogenik pada Teluk Kelabat dapat memberikan kontribusi bahan organik dan berdampak negatif terhadap ekosistem perairan. Ak+ibat hal tersebut, keseimbangan alami antara produksi dan dekomposisi bahan organik dapat terganggu di Teluk Kelabat.
Memahami kandungan dan sumber masukan bahan organik pada sedimen merupakan tools yang penting dalam memahami lingkungan perairan serta kajian awal untuk mempelajari senyawa organik spesifik (lipid biological marker). Informasi tentang distribusi bahan organik pada perairan Teluk Kelabat belum terdokumentasikan. Penelitian dilaksanakan dengan tujuan mengkaji distribusi bahan organik pada sedimen serta identifikasi sumber bahan organik perairan Teluk Kelabat.

\section{MATERI DAN METODE}

Sedimen yang digunakan pada penelitian ini dikoleksi dari 11 stasiun pada perairan Teluk Kelabat (Gambar 1). Pengambilan sampel sedimen dilakukan pada bulan Juni 2019. Sedimen permukaan $( \pm 2-4 \mathrm{~cm})$ dikoleksi dengan menggunakan alat grab. Setelah dikoleksi, sampel dihomogenisasi dan disimpan pada suhu $4^{\circ} \mathrm{C}$ hingga analisis lebih lanjut (Gao et al., 2012).

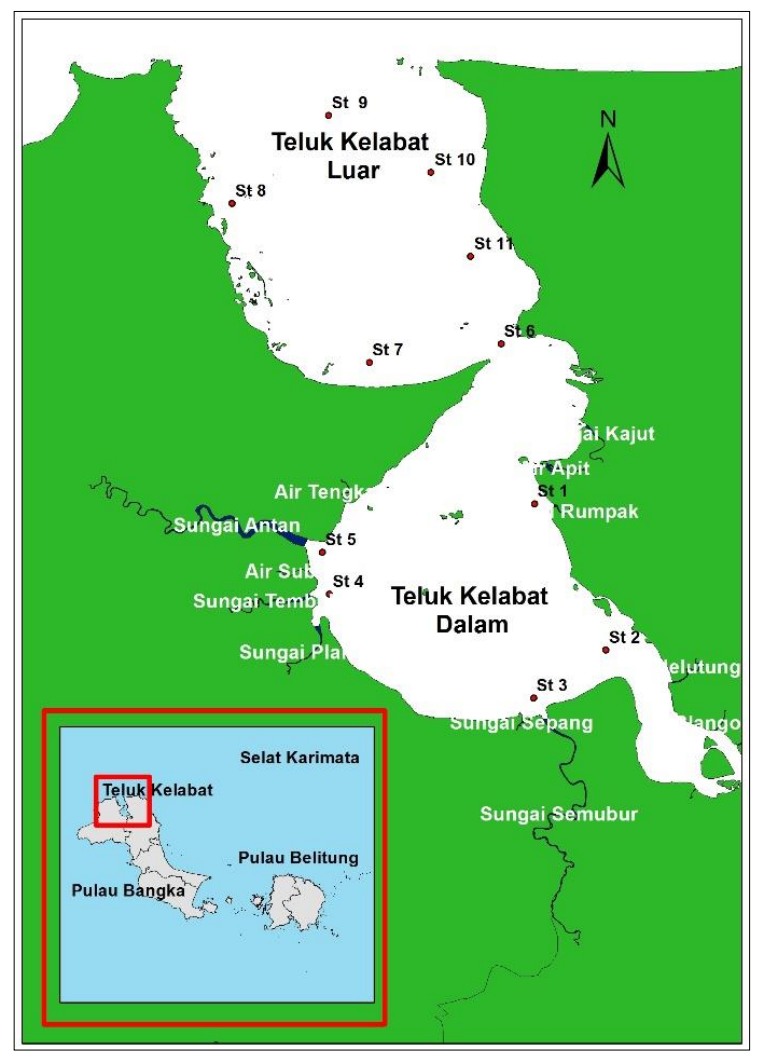

Gambar 1. Peta lokasi penelitian di Perairan Teluk Kelabat 
TOC sedimen diukur menggunakan metode Walkley Black (Welcherr, 1975). Sampel sedimen sebanyak 0,05 $\mathrm{mg}$ diberi larutan $\mathrm{K}_{2} \mathrm{Cr}_{2} \mathrm{O}_{7} 0,2 \mathrm{~N}(10 \mathrm{~mL})$. Selanjutnya ditambahkan $\mathrm{H}_{2} \mathrm{SO}_{4}$ pekat $(20 \mathrm{~mL}$ ) digojog selama 1 menit, kemudian didiamkan selama 30 menit. Ditambah $200 \mathrm{~mL}$ aquades, $10 \mathrm{~mL}$ $\mathrm{H}_{3} \mathrm{PO}_{4} 85 \%$ dan $0,5 \mathrm{~mL}$ indikator kemudian digojog dan biarkan dingin. Dititar dengan Ferro sulfat 0,2 N. TN sedimen diuji dengan metode Kjeldahl (Badan Standardisasi Nasional, 2013; SNI 4146:2013). Tekstur sedimen dianalisis dengan menggunakan metode pipet (Holme and Mc Intyre, 1984). Nilai ukuran butiran sedimen yang diperoleh diklasifikasi berdasarkan klasifikasi Wenworth. Persentase ukuran butiran dibagi dalam tiga kelompok yaitu <4 $\mu \mathrm{m}$ (liat), 4-63 $\mu \mathrm{m}$ (lumpur), dan $>63 \mu \mathrm{m}$ (pasir) (Gao et al., 2012).

\section{HASIL DAN PEMBAHASAN}

Tekstur sedimen yang diperoleh pada perairan Teluk Kelabat bervariasi (Tabel 1). Untuk pasir (>63 $\mu \mathrm{m})$ persentase yang diperoleh berkisar antara 8,27-9,06\%. Persentase lumpur $(4-63 \mu \mathrm{m})$ yang diperoleh berkisar antara 0,47-60,25\%. Selanjutnya, persentase liat $(<4 \mu \mathrm{m})$ berkisar antara 1,04$32,79 \%$. Untuk partikel halus dengan ukuran butiran $<63 \mu \mathrm{m}$ (lumpur + liat) berkisar antara $3,94-91,73 \%$.
Pada Teluk Kelabat bagian dalam, terlihat partikel halus/ lumpur + liat (rata-rata 72,78\%; Gambar 2) lebih dominan bila dibandingkan dengan partikel halus pada Teluk Kelabat bagian luar (rata-rata 21,45\%). Untuk fraksi pasir (Gambar 3) terlihat lebih dominan atau tinggi proporsinya pada Teluk Kelabat bagian luar (rata-rata 98,55\%) bila dibandingkan dengan fraksi pasir pada Teluk Kelabat bagian dalam (rata-rata 28,01\%).

Perairan dengan kondisi yang relatif tenang/ kecepatan arus yang relatif lemah, proporsi dari partikel halus pada sedimen menjadi dominan terdeposisi (Prartono et al., 2009). Sebaliknya, bila perairan laut yang kecepatan arusnya relatif kuat, proporsi fraksi pasir akan relatif dominan terdeposisi (Prartono et al., 2009). Dominannya partikel halus yang terdeposisi pada Teluk Kelabat bagian dalam bila dibandingkan dengan bagian luar diperkuat oleh penelitian dari Pamungkas dan Farhaby (2018) yang menemukan bahwa perairan Teluk Kelabat bagian dalam, memiliki kecepatan arus yang relatif lebih lemah bila dibandingkan Teluk Kelabat bagian lvar.

Nilai partikel halus/ lumpur + liat pada Teluk Kelabat (3,94-91,73\%) masih lebih rendah bila dibandingkan dengan dengan partikel halus pada perairan Teluk Persia yaitu

Tabel 1. Persentase ukuran butiran sedimen (\%) yang diperoleh pada perairan Teluk Kelabat

\begin{tabular}{|c|c|c|c|c|c|}
\hline \multirow{2}{*}{ Stasiun } & \multicolumn{4}{|c|}{ Tekstur sedimen (\%) } & \multirow[t]{2}{*}{ Keterangan } \\
\hline & Pasir & Lumpur & Liat & Lumpur + Liat & \\
\hline 1 & 8,27 & 60,25 & 31,48 & 91,73 & \multirow{5}{*}{$\begin{array}{l}\text { Teluk Kelabat } \\
\text { bagian dalam }\end{array}$} \\
\hline 2 & 25,20 & 47,44 & 27,36 & 74,80 & \\
\hline 3 & 26,34 & 40,87 & 32,79 & 73,66 & \\
\hline 4 & 43,41 & 33,02 & 23,57 & 56,59 & \\
\hline 5 & 36,84 & 50,06 & 13,10 & 63,16 & \\
\hline 6 & 96,06 & 0,47 & 3,47 & 3,94 & \multirow{6}{*}{$\begin{array}{c}\text { Teluk Kelabat } \\
\text { bagian luar }\end{array}$} \\
\hline 7 & 67,98 & 12,12 & 19,90 & 32,02 & \\
\hline 8 & 85,64 & 9,48 & 4,89 & 14,37 & \\
\hline 9 & 61,22 & 12,14 & 26,64 & 38,78 & \\
\hline 10 & 89,80 & 2,67 & 7,53 & 10,20 & \\
\hline 11 & 92,07 & 6,89 & 1,04 & 7,93 & \\
\hline
\end{tabular}




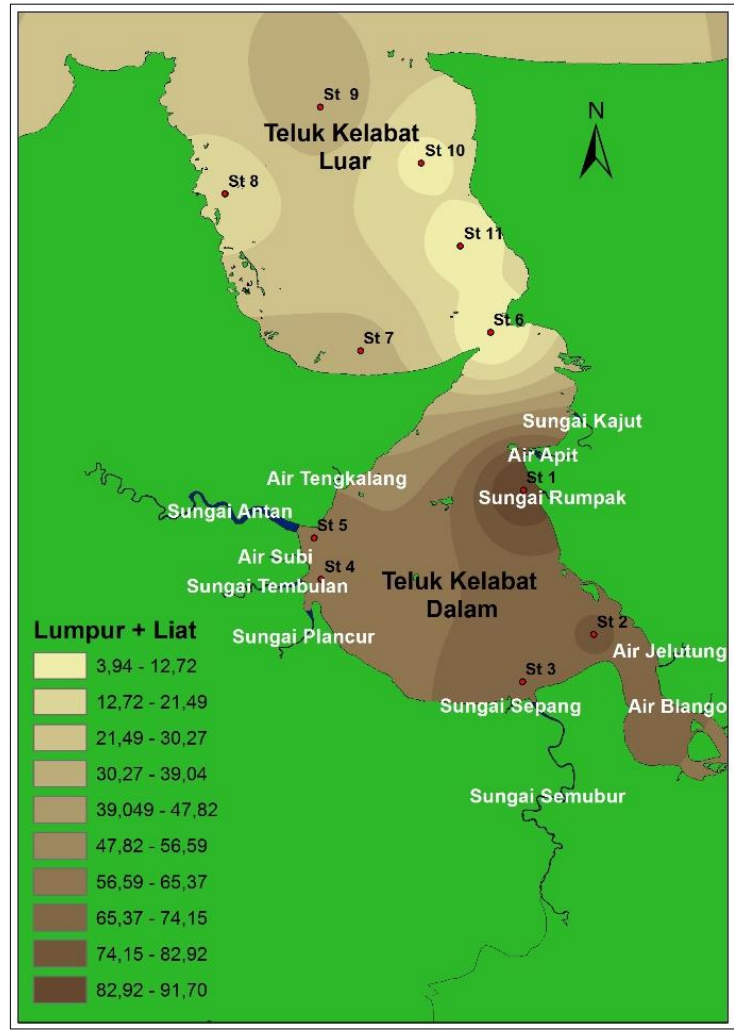

Gambar 2. Distribusi fraksi lumpur + liat pada sedimen perairan Teluk Kelabat

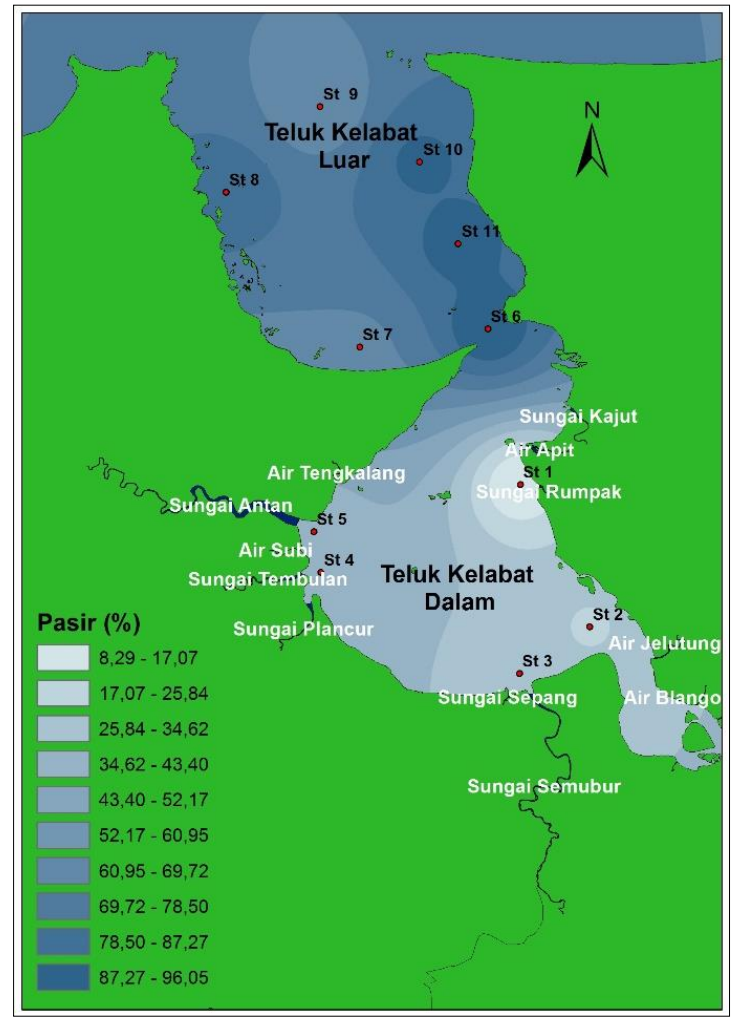

Gambar 3. Distribusi fraksi pasir pada sedimen perairan Teluk Kelabat 
berkisar antara 34,9-100\% (Homira et al., 2013). Sebaliknya, nilai partikel halus/ lumpur + liat pada Teluk Kelabat masih lebih tinggi bila dibandingkan dengan perairan Laguna Chilika yaitu 4-16\% (Nazneen dan Raju, 2017), Belitung yaitu 3,21-81,65\% (Putri et al., 2015), dan Pulau Tikus yaitu $0,116-45,42 \%$ (Hakim et al., 2015).

\section{Distribusi TOC dan TN pada Sedimen Permukaan Teluk Kelabat}

Nilai TOC (Tabel 2) yang diperoleh pada sedimen perairan Teluk Kelabat berkisar antara $0,04-7,25 \%$. Konsentrasi rata-rata TOC pada Teluk Kelabat bagian dalam dan luar yaitu $5,78 \%$ dan $0,57 \%$. Nilai rata-rata tertinggi terdapat pada Teluk Kelabat bagian dalam. US EPA (2002) membagi 3 kategori penilaian TOC dalam sedimen yaitu rendah $(\leq 1 \%)$, sedang (>1 hingga $3 \%)$, dan Tinggi (>3\%). Nilai TOC yang diperoleh di perairan Teluk Kelabat berada pada level rendah hingga tinggi. Pada Teluk Kelabat bagian dalam nilai TOC yang diperoleh tinggi, sedangkan bagian luar rendah hingga sedang. Masukan bahan organik yang diperoleh di perairan Teluk Kelabat dapat berasal dari antropogenik maupun alami. Sumber senyawa organik secara alami dapat berasal akuatik dan terestrial (Gao et al., 2012;, Gu et al., 2017).

Tabel 2. Konsentrasi total organic carbon (\%) dan total nitrogen (\%) pada sedimen perairan Teluk Kelabat

\begin{tabular}{cccc}
\hline Stasiun & TOC (\%) & TN (\%) & Keterangan \\
\hline 1 & 7,19 & 0,13 & \\
2 & 4,23 & 0,14 & Teluk \\
3 & 7,25 & 0,11 & Kelabat \\
bagian \\
4 & 6,71 & 0,14 & dalam \\
5 & 3,53 & 0,08 & \\
6 & 0,11 & 0,08 & \\
7 & 2,35 & 0,06 & \\
8 & 0,04 & 0,06 & Teluk \\
9 & 0,12 & 0,04 & Kelabat \\
10 & 0,16 & 0,06 & \\
11 & 0,05 & 0,07 & \\
\hline
\end{tabular}

Tinggi dan rendahnya TOC yang diperoleh pada Teluk Kelabat bila dikaitkan dengan tekstur sedimen yang diperoleh, sangat menentukan kandungan karbon organik total (Prartono et al., 2009). Gambar 4 menunjukkan nilai TOC memiliki hubungan positif yang signifikan dengan fraksi halus sedimen. Hal tersebut mengindikasikan bahwa variasi TOC pada Teluk Kelabat dipengaruhi oleh fraksi halus sedimen. Pada perairan dengan komposisi pasir relatif tinggi umumnya mengandung karbon organik yang lebih rendah dibandingkan dengan komposisi partikel halus (lumpur dan liat). Teluk Kelabat bagian dalam memiliki komposisi partikel halus lebih dominan bila dibandingkan dengan Teluk Kelabat bagian luar (Gambar 5).

Konsentrasi TOC dalam sedimen yang diperoleh masih lebih rendah bila dibandingkan dengan TOC sedimen yang ditemukan pada perairan muara Sungai Banjir Kanal Timur, Semarang yaitu berkisar 1035\% (Diyat et al., 2015), Perairan Laut Belitung yaitu berkisar 0,78-12,05\% (Putri et al., 2015), dan Perairan Pulau Tikus Bengkulu yaitu berkisar 4,1-12,2\% (Hakim et al., 2015).

Nilai TN (Tabel 2) yang diperoleh pada sedimen perairan Teluk Kelabat berkisar antara 0,04-0,14\%. Konsentrasi rata-rata TN pada Teluk Kelabat bagian dalam dan luar yaitu $0,12 \%$ dan $0,07 \%$ dengan konsentrasi rata-rata tertinggi terdapat pada bagian dalam (Gambar 6). Nilai TN yang diperoleh pada Teluk Kelabat bagian dalam dan luar termasuk masih rendah (TN $<0,2 \%$ ),

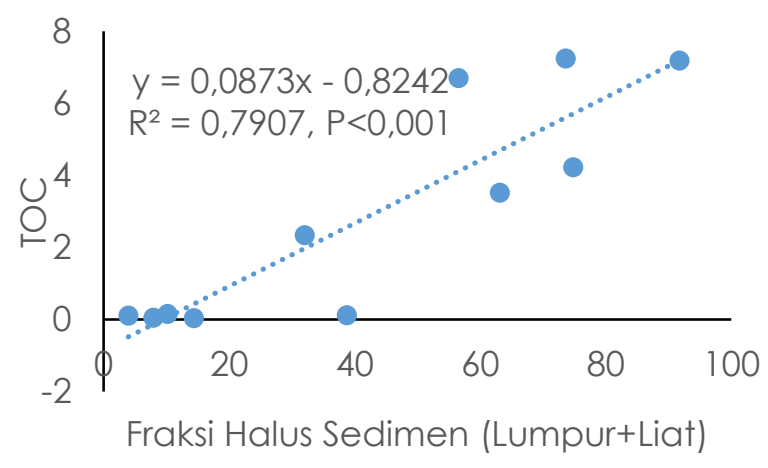

Gambar 4. Hubungan antara TOC dan Fraksi halus sedimen pada perairan Teluk Kelabat 


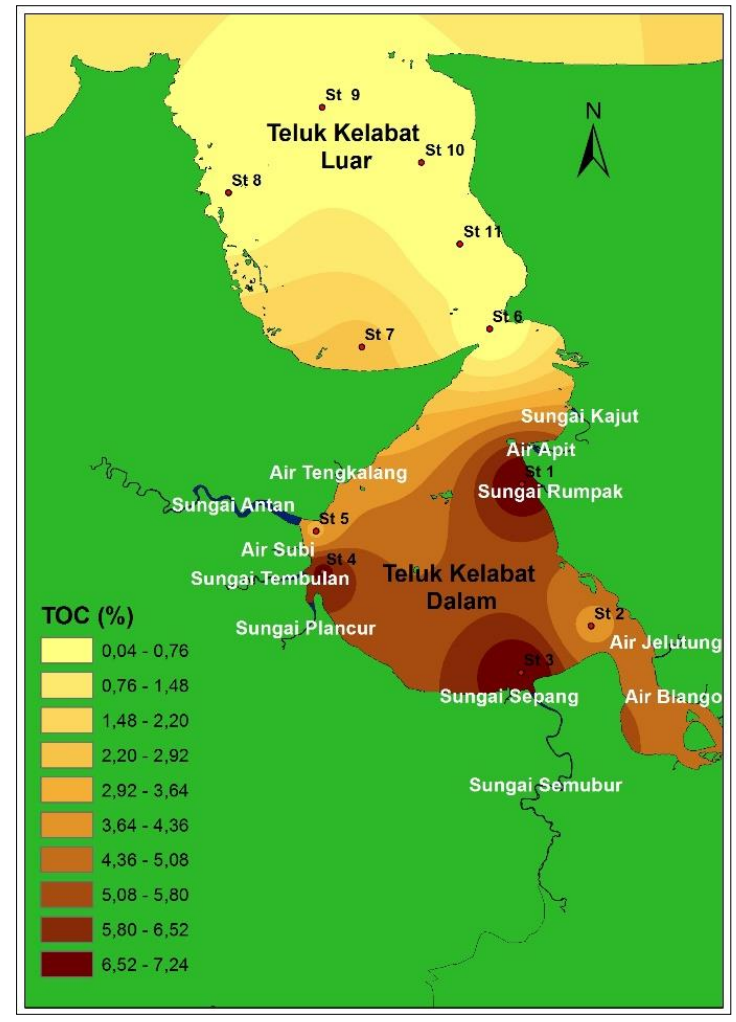

Gambar 5. Distribusi TOC pada sedimen perairan Teluk Kelabat

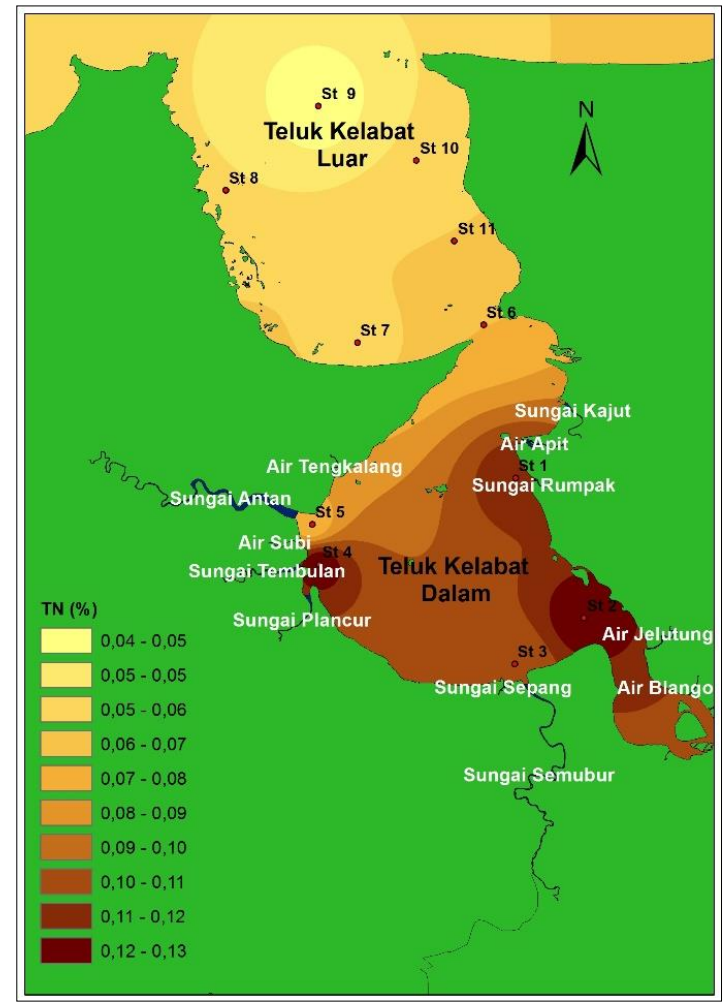

Gambar 6. Distribusi TN pada sedimen perairan Teluk Kelabat 
sedangkan bila nlilai TN $>0,2 \%$ termasuk kategori tinggi (Silva et al., 2011). Konsentrasi TN yang ditemukan pada Teluk Kelabat masih lebih rendah bila dibandingkan dengan yang ditemukan pada Teluk Zhelin, Cina (kisaran 0,08-0,20\% dengan rata-rata 0,15) (Gu et al., 2017). Selanjutnya, bila dibandingkan dengan TN sedimen yang ditemukan oleh Wang et al., (2016) yaitu berkisar antara 0,01$0,05 \%$ di Teluk Zhifu-Cina, nilai TN pada Teluk Kelabat masih lebih tinggi.

\section{Sumber Bahan Organik (Rasio $\mathrm{C} / \mathrm{N}$ ) pada Sedimen Permukaan Teluk Kelabat}

Nilai rasio $\mathrm{C} / \mathrm{N}$ (Tabel 3) yang diperoleh pada sedimen perairan Teluk Kelabat berkisar antara 0,67-65,91. Rasio elemen $\mathrm{C} / \mathrm{N}$ sering digunakan sebagai indikator/ penilaian sumber bahan organik (kontribusi relatif bahan organik dari laut dan terestrial) pada ekosistem perairan (Gao et al., 2012; Spano et al., 2014). Secara umum, nilai rasio $C / N$ lebih dari 12 mengindikasikan adanya masukan dari terestrial (Lamb et al., 2006; Gao et al., 2012; Wang et al., 2018). Sedangkan nilai rasio C/N $5-8$ dan $<10$ mengindikasikan adanya masukan dari akuatik (bakteri dan alga) (Yu et al., 2010; Gao et al., 2012; Spano et al., 2014; Wang et al., 2018).

Nilai $\mathrm{C} / \mathrm{N}$ memiliki hubungan positif yang signifikan (Gambar 7) dengan konsentrasi TOC. Hal tersebut mengindikasikan bahwa variasi rasio $\mathrm{C} / \mathrm{N}$

Tabel 3. Rasio TOC/TN pada sedimen perairan Teluk Kelabat

\begin{tabular}{ccc}
\hline Stasiun & Rasio C/N & Keterangan \\
\hline 1 & 55,31 & \\
2 & 30,21 & Teluk Kelabat \\
3 & 65,91 & bagian dalam \\
4 & 47,93 & \\
5 & 44,13 & \\
6 & 1,38 & \\
7 & 39,17 & \\
8 & 0,67 & Teluk Kelabat \\
9 & 3,00 & bagian luar \\
10 & 2,67 & \\
11 & 0,71 & \\
\hline
\end{tabular}

pada Teluk Kelabat dipengaruhi oleh konsentrasi TOC. Pada penelitian ini material terestrial yang masuk ke sungai dapat menjadi sumber yang penting dari bahan organik pada sedimen permukaan Teluk Kelabat.

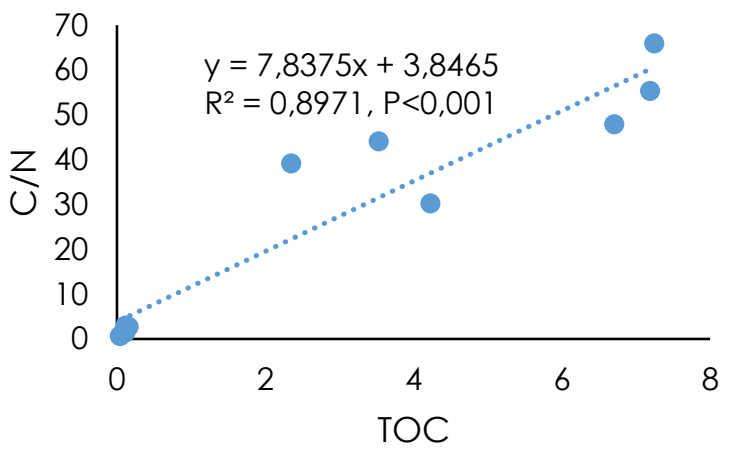

Gambar 7. Hubungan antara $\mathrm{C} / \mathrm{N}$ dan TOC pada sedimen permukaan Teluk Kelabat

Nilai C/N Teluk Kelabat bagian dalam mengindikasikan masukan bahan organik utamanya dari terestrial $(\mathrm{C} / \mathrm{N}>12)$. Bila dibandingkan dengan Teluk Kelabat bagian luar masukan bahan organik utamaya berasal akuatik $(\mathrm{C} / \mathrm{N}<10)$ (Homira et al., 2013). Gao et al. (2012) juga menemukan dominannya kontribusi bahan organik dari terestrial (berkisar antara 10,8-42,6) pada sedimen Teluk Bohai, Cina. Selanjutnya, Burone et al. (2003) mendapatkan nilai rasio $\mathrm{C} / \mathrm{N}$ berkisar antara 7,6-15,0 pada Teluk Ubatuba, Brasil. Nilai yang diperoleh tersebut merefleksikan masukan bahan organik adalah campuran baik dari terestrial maupun akuatik. Kondisi tersebut sama dengan yang ditemukan pada Teluk Kelabat (Gambar 8).

\section{KESIMPULAN}

Pola distribusi TOC, TN, serta rasio $\mathrm{C} / \mathrm{N}$ pada sedimen Teluk Kelabat memperlihatkan nilai pada Teluk Kelabat bagian dalam lebih tinggi dibandingkan bagian luar. Sumber masukan bahan organik pada Teluk Kelabat bagian dalam utamanya berasal dari terestrial, sedangkan Teluk Kelabat bagian luar utamanya berasal dari akuatik. Perbedaan pola distribusi dan kontribusi bahan organik tersebut dipengaruhi oleh faktor hidrodinamika dan masukan dari sungai. 


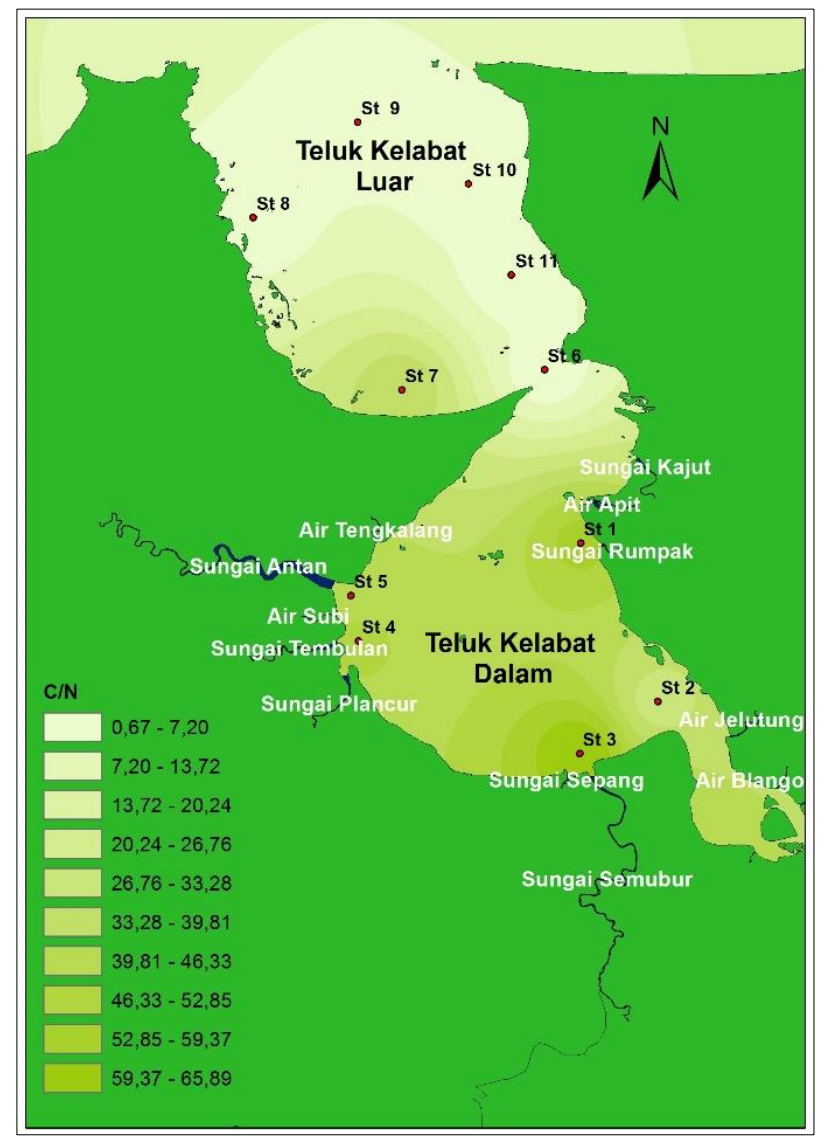

Gambar 8. Distribusi rasio C/N pada sedimen perairan Teluk Kelabat

\section{UCAPAN TERIMA KASIH}

Penelitian ini didukung oleh Kemenristekdikti, Lembaga Penelitian dan Pengabdian kepada Masyarakat (LPPM) Universitas Bangka Belitung melalui dana skema Penelitian Dosen Pemula (PDP) Kemenristekdikti Tahun 2019.

\section{DAFTAR PUSTAKA}

Burone, L., Muniz, P., Pires-Vanin, A.M.S., \& Rodrigues, M., 2003, Spatial distribution of organic matter in the surface sediments of Ubatuba Bay (Southeastern - Brazil), An/ Brazilian. Acad. Sci., 75(1):77-90, doi: 10.1590/S000 1-37652003000100009

Diyat, J.W., Wulandari, S.Y., \& Muslim, 2015, Sebaran kandungan total fosfat dan karbon organik di Perairan Muara Sungai Banjir Kanal Timur, Semarang, J. Oseanograf., 4(1):55-63.

Gao, X., Yang, Y., \& Wang, C., 2012, Geochemistry of organic carbon and nitrogen in surface sediments of coastal Bohai Bay inferred from their ratios and stable isotopic signatures. Mar. Poll. Bull., 64(2012):1148-1155, doi: 10.1016/j.marpol bul.2012.03.028

Gu, Y.G., Ouyang, J., Ning, J.J., \& Wang, Z.H., 2017, Distribution and sources of organic carbon, nitrogen and their isotopes in surface sediments from the largest mariculture zone of The Eastern Guangdong Coast, South China. Mar. Poll. Bull., 120(1-2):286-291, doi: 10.1016/j. marpolbul.2017.05.013

Hakim, A.R., Muslim, \& Makmur, M., 2015, hubungan ukuran butir sedimen dengan kandungan total organik carbon pada sedimen Perairan Pulau Tikus, Bengkulu, J. Oseanograf., 4(3):585-589.

Holme, N.A. \& Mc Intyre, A.D., 1984, Methods for the study of marine benthos. 2nd edition, Oxford: Blackwell Scientific Publication, 387p.

Homira, A., Shirin, R., Fumani, S., \& Neda, 2013, Organic carbon and organic 
matter levels in sediments of the Strait of Hormoz, the Persian Gulf, J. Persian Gulf, $4(13): 31-37$.

Lamb, A.L., Wilson, G.P., \& Leng, M.J., 2006, A review of coastal palaeoclimate and relative sea-level reconstructions using $\delta 13$ $\mathrm{C}$ and $\mathrm{C} / \mathrm{N}$ ratios in organic material, Earth Sci. Rev., 75(2006):29-57, doi: 10.1016/j.earscirev.2005.10.003

Li, Y., Zhang, H., Tu, C., Fu, C., Xue, Y., \& Luo, $Y$., 2016, Sources and fate of organic carbon and nitrogen from land to ocean: Identified by coupling stable isotopes with $\mathrm{C} / \mathrm{N}$ ratio, Estuar. Coast. Shelf Sci., $181(2016): 114-122$, doi: 10.1016/j.ecss. 2016.08 .024

Nazneen, S. \& Raju, N.J. 2017. Distribution and Sources of Carbon, Nitrogen, Phosphorus and Biogenic Silica in The Sediments of Chilika Lagoon, J. Earth Syst. Sci., 126 : 113. doi: 10.1007/s12040-016-0785-8

Pamungkas, A. \& Farhaby, A.M., 2018, Hydrooceanography modelling characteristic (tidal, waves, and currents) in Kelabat Bay, Bangka Belitung. Int. Conferen. Maritime and Archipelago (ICOMA 2018), Adv. Eng. Res., Volume 167, Atlantis Press, doi: $10.2991 /$ icoma-18.20 19.38

Prartono, T., Razak, H., \& Gunawan, I., 2009, Pestisida organoklorine di Sedimen Pesisir Muara Citarum, Teluk Jakarta: peran penting fraksi halus sedimen sebagai pentransport DDT dan proses diagenesanya. J. Ilmu Teknol. Kel. Trop., 1 (2): 1 1-21, doi: 10.29244 /jitkt.vli2.7869

Putri, R.A.P., Muslim, \& Makmur, M., 2015, Sebaran karbon organik total pada Sedimen di Perairan Laut Belitung, J. Oseanograf., 4(4):765-770.

Silva, N., Vargas, C.A., \& Prego, R., 2011, Land-Ocean distribution of allochthonous organic matter in surface sediments of The Chiloe And Aysen
Interior Seas (Chilean Northern Patagonia), Cont. Shelf Res., 31:330-339, doi: 10.1016/j.csr.2010.09.0 09

SNI (Standar Nasional Indonesia) 4146:2013. 2013. Cara uji kadar nitrogen total sedimen dengan distilasi kjeldahl secara titrasi. Badan Standarisasi Nasional.

Spano, S., Belem, A.L., Doria, R.N., Zucchi, M.D.R., Souza, J.R.B.D., Costa, A.B., Lentini, C.A.D., \& Azevedo, A.E.G.D., 2014, Application of organic carbon and nitrogen stable isotope and $\mathrm{C} / \mathrm{N}$ ratios as source indicators of organic matter ff Noviçosa-Caravelas Estuarine Complex, Southern Bahia, Brazil, Brazilian J. Geol, 44(1):13-21, doi: 10.5327/Z2317-48892014 00010003

U.S. Environmental Protection Agency (EPA), 2002, Mid-Atlantic Integrated Assessment (MAIA) Estuaries 1997-98: Summary Report, EPA/620/R-02/003,115 pp.

Wang, C., LV, Y., \& Li, Y., 2018, Riverine input of organic carbon and nitrogen in watersediment system from the Yellow River estuary reach to the coastal zone of Bohai Sea, China, Cont. Shelf Res., 157(2018):1-9, doi: 10.1016/j.csr.2018.02.004

Wang, Z., LU, X., and Zhang, K., 2016, Distribution and contamination of metals and biogenic elements in sediments from Zhifu Bay of The Yellow Sea, China, J. Environ. Sci., 41:6-15, doi: 10.1016/j.jes. 2015.06.009

Welcherr, F.J. 1975. Standard methods of chemical analysis, Sixth edition, Vol.2, R.E.Krieger Pub. Co., 1372p.

Yu, F., Zong, Y., Lloyd, J.M., Huang, G., Leng, M.J., Kendrick, C., Lamb, A.L., \& Yim, W.W.S., 2010. Bulk organic $\delta^{13} \mathrm{C}$ and $\mathrm{C} / \mathrm{N}$ as indicators for sediment sources in the Pearl River delta and estuary, southern China, Estua. Coast. Shelf Sci., 87:618-630, doi: 10.1016/ j.ecss.2010.02.018 